\title{
Efektifitas Metode Permainan Media Kartu Bergambar dalam Meningkatkan Kemampuan Membaca Aksorn di Thailand
}

\author{
Isnaeni Pangestika ${ }^{\bowtie}$, Achmad Rifai, U. Utsman
}

Jurusan Pendidikan Luar Sekolah, FIP Universitas Negeri Semarang

\begin{tabular}{l} 
Info Artikel \\
\hline Sejarah Artikel: \\
Diterima Maret 2017 \\
Disetujui Mei 2017 \\
Dipublikasikan Juni 2017
\end{tabular}

\section{Keywords:}

games method; card media; read; aksorn; $P A U D$

\begin{abstract}
Abstrak
Penelitian ini bertujuan menguji dan mendeskripsikan keefektifan metode permainan media kartu bergambar dalam meningkatkan kemampuan membaca aksorn pada PAUD Ban Klong-To di Thailand. Jenis penelitian ini adalah pre-eksperimen dengan desain One Group Pretest Posttest. Subjek penelitian adalah kelompok B PAUD Ban KlongTo sejumlah 25 siswa. Hasil penelitian menunjukkan rata-rata nilai posttest 8,3 lebih besar dibandingkan nilai pretest yang sebesar 3,4. Hasil uji-t menunjukkan nilai t-hitung $(14,462)>$ t-tabel $(1,708)$ serta perhitungan hasil gain score sebesar 0,75 dengan kategori tinggi. Hasil penelitian menunjukkan bahwa metode permainan media kartu bergambar terbukti efektif diterapkan terhadap pembelajaran membaca pada anak usia dini.
\end{abstract}

\begin{abstract}
This study aims to examine and describe the method effectiveness of cards game media in improving reading skills in early childhood aksorn Ban Klong-To in Thailand. The research is a pre-experiment with One Group Pretest Posttest design. The subjects were a group B Ban Klong-To Kindergarten a number of 25 students. The results showed the average value of greater than 8.3 posttest pretest value of 3.4. The results of $t$-test showed the value of $t$-test (14.462) $>t$ table (1.708) as well as the calculation results of gain score of 0.75 with a high category. Based on these results, it could be conclude that the game method proved effective card media applied to learning reading in early childhood.
\end{abstract}

(C) 2017 PLS FIP UNNES

$\triangle$ Alamat korespondensi:

E-mail: isnaeni.pangestika@gmail.com

\section{PENDAHULUAN}

Pendidikan merupakan suatu kegiatan universal dalam kehidupan manusia. Karena pada hakikatnya, pendidikan merupakan usaha manusia untuk memanusiakan manusia itu sendiri, yaitu untuk memberdayakan manusia. Meskipun pendidikan merupakan gejala yang umum dalam setiap kehidupan masyarakat, namun perbedaan filsafat dan pandangan hidup yang dianut oleh masing-masing bangsa atau masyarakat dan bahkan individu menyebabkan perbedaan penyelenggaraan kegiatan pendidikan tersebut, dengan demikian selain bersifat universal pendidikan juga bersifat nasional.

Pada hakikatnya pendidikan berarti setiap usaha sadar yang bertujuan untuk mengubah sikap dan tingkah laku seseorang atau anak didik. Pendidikan juga merupakan aktivitas dan usaha manusia untuk meningkatkan kepribadian dengan jalan membina potensi-potensi pribadi, yaitu rohani (pikir, karsa, cipta, dan budi nurani) dan jasmani (panca indera serta keterampilanketerampilan). Morisson (2012) mengungkap bahwa sasaran Pendidikan prasekolah pada bidang pengembangan bahasa meliputi beberapa 
dimensi perkembangan yaitu interaksi dengan orang dewasa dan rekan sebagai sarana mengembangkan bahasa lisan; membantu anak menambah kosa kata; membantu anak belajar bercakap-cakap dengan anak dan orang dewasa lain; mengasah kefasihan bahasa; mengembangkan keterampilan baca tulis; mempelajari huruf alfabet dan mengenal berbagai jenis buku.

Pendidikan anak usia dini penting dilaksanakan sebab anak usia 0-6 tahun berada pada masa peka, yaitu masa dimana seluruh potensi anak dapat dikembangkan secara optimal baik dalam aspek fisik, bahasa, kognitif, sosial-emosional, maupun moral-agama. Kelima aspek perkembangan tersebut tidak dapat dipisahkan satu dengan yang lainnya. Meskipun demikian bahasa memiliki peran yang sangat penting dalam tumbuh kembang anak terutama dalam membantu seseorang untuk berinteraksi dan berkomunikasi dengan orang lain. Anak dapat mengungkapkan segala keinginannya maupun ide-idenya kepada orang lain, hal ini mempengaruhi perkembangan anak. Bahasa akan membantu anak untuk memperoleh pengetahuan-pengetahuan baru dari berinteraksi dengan orang lain tersebut.

Musthofa (2007:10) mengungkapkan bahwa "Anak usia dini adalah manusia yang masih kecil, dapat pula diartikan anak usia dini merupakan anak yang sedang mengalami masa kanak-kanak awal, yaitu anak yang berusia sampai dengan 6 tahun". Sedangkan Mansur (2005:18) mengungkapkan bahwa "Anak usia dini adalah anak usia lahir sampai memasuki pendidikan dasar". Menurut Zubaidah (2004) mengungkapkan bahwa perkembangan bahasa anak mencakup empat keterampilan. Empat keterampilan bahasa yang dimaksud meliputi keterampilan menyimak, keterampilan berbicara, keterampilan membaca, dan keterampilan menulis.

Kemampuan membaca mengacu pada kecakapan (ability) yang harus dikuasai pembaca yang berada dalam tahap membaca kecakapan yang dimaksud adalah penguasaan kode alfabetik, dimana pembaca hanya sebatas membaca huruf per huruf, menggabungkan fonem menjadi suku kata atau kata. Berdasarkan Mulyati (2015:16) (Mulyati, 2013:16), "Perkembangan membaca awal merupakan proses interaktif di mana anak adalah peserta aktif". Sebaiknya pendekatan keahlian dasar dan fonik menekankan bahwa pembelajaran membaca seharusnya mengajarkan fonik dan aturan-aturan dasarnya dalam menerjemahkan simbolsimbol kedalam bunyi. "Pelajaran membaca awal sebaiknya melibatkan materi-materi yang disederhanakan" (Santrock, 2009:120).

Patmonodewo (2003) mengemukakan 3 hal yang perlu diketahui dalam perkembangan bahasa pada anak. Pertama adalah perbedaan antara bahasa dan kemampuan berbicara. Bahasa merupakan sistem tata bahasa, sedangkan kemampuan bicara merupakan ungkapan dalam bentuk kata-kata. Kedua pertumbuhan bahasa yaitu bersifat pengertian atau reseptif dan bersifat ekspresif. Kemampuan untuk memahami merupakan kemampuan reseptif, sedangkan kemampuan kemampuan menunjukan bahasa merupakan ekspresif. Ketiga komunikasi diri pada saat berhayal perlu dibatasi.

Selama ini anak usia dini menggunakan alat peraga Aksorn Thailand untuk untuk memperoleh kemampuan membaca dan menulis. Kartu bergambar adalah gambar Aksorn Thailand yang dituangkan pada selembar karton berbentuk kartu yang cukup besar. Kartu-kartu tersebut memuat Aksorn Thailand yang ditulis dengan Aksorn Thailand anak hanya mengamati Aksorn Thailand yang tertuang pada kartu. Kriteria yang paling utama dalam pemilihan media bahwa media harus disesuaikan dengan tujuan pembelajaran atau kompetensi yang ingin dicapai. Hasil penelitian menunjukkan bahwa kegiatan belajar mengajar akan lebih efektif dan mudah bila dibantu dengan sarana visual, dimana $11 \%$ dari yang dipelajari terjadi lewat indera pendengaran dan $83 \%$ lewat indera penglihatan. Bentukbentuk stimulus bisa dipergunakan sebagai media diantaranya adalah hubungan atau interaksi manusia, realita, gambar bergerak atau tidak, tulisan dan suara yang direkam. Di dalam 
situasi proses pendidikan untuk anak usia dini juga terdapat pesan yang harus dikomunikasikan. Pesan tersebut biasanya merupakan isi dari tema atau topik kegiatan belajar yang disampaikan melalui suatu media dengan menggunakan suatu metode.

Berhubungan dengan tujuan kemampuan membaca Aksorn Thailand, dengan tujuan untuk meningkatkan kemampuan membaca Aksorn Thailand siswa sehingga dapat memahami makna, ide atau gagasan wacana yang dibaca. Melalui metode permainan media kartu bergambar diharapkan siswa bisa termotivasi untuk membaca Aksorn Thailand secara intensif sehingga memahami ide, gagasan dan makna dalam bacaan. Erat kaitannya dengan memberikan motivasi dalam kemampuan membaca ini adalah pemberian contoh membaca yang baik dan benar dari guru. Seorang guru harus menguasai cara mengajar yang baik dan dituntut dapat menggunakan media yang ramah dalam situasi dan kondisi bagaimana pun. Salah satu media yang tepat yang dapat diterapkan untuk meningkatkan kemampuan membaca Aksorn Thailand ini adalah media kartu bergambar.

Usia 0-6 tahun merupakan usia emas (the golden age) yaitu masa peka yang hanya datang sekali. Masa peka adalah masa perkembangan anak dikembangkan secara optimal. Usia perkembangan anak usia dini dalam rentang 0-6 tahun dan termasuk dalam usia anak taman kanak-kanak. Pada usia dini harus sudah mengenal huruf saat keluar dari pendidikan anak usia dini, sehingga saat memasuki sekolah dasar anak tidak mengalami kesulitan untuk menguasai keterampilan membaca.

Sehubungan dengan hal tersebut, dari hasil diskusi dan observasi yang dilakukan di Kelompok B PAUD Ban Klong-To diperoleh hasil kemampuan bahasa khususnya kemampuan membaca Aksorn Thailand belum berkembang secara optimal dibandingkan dengan kemampuan-kemampuan lainnya, seperti kemampuan fisik motorik, kognitif, dan sosial-emosional. Berdasarkan hasil pengamatan tersebut terdapat permasalahan yang terkait dengan kemampuan membaca huruf. Diantaranya sebagian besar anak belum membaca semua huruf-huruf, hal ini terlihat pada saat anak mengalami kesulitan dalam pembelajaran.

Hasil penelitian menunjukkan bahwa kegiatan belajar mengajar akan lebih efektif dan mudah bila dibantu dengan sarana visual, dimana $11 \%$ dari yang dipelajari terjadi lewat indera pendengaran dan $83 \%$ lewat indera penglihatan. Bentuk-bentuk stimulus bisa dipergunakan sebagai media diantaranya adalah hubungan atau interaksi manusia, realita, gambar bergerak atau tidak, tulisan dan suara yang direkam. Di dalam situasi proses pendidikan untuk anak usia dini juga terdapat pesan yang harus dikomunikasikan. Pesan tersebut biasanya merupakan isi dari tema atau topik kegiatan belajar yang disampaikan melalui suatu media dengan menggunakan suatu metode.

Kemampuan anak dalam membaca aksorn Thailand belum berkembang, dari 20 anak dalam kelas baru 3 anak yang mampu membaca aksorn Thailand dengan baik. Anak nampak kesulitan saat menyebutkan aksorn Thailand. Anak juga terbalik saat menyebutkan aksorn Thailand dengan lafal ataupun bentuknya mirip. Anak juga kesulitan saat diminta menyebutkan kata dari sebuah aksorn Thailand, begitu pula sebaliknya saat diminta untuk menyebutkan aksorn Thailand depan dari sebuah kata.

Oleh karena itu untuk mengatasi permasalahan tersebut, penelitian ini berkolaborasi untuk menggunakan metode permainan dengan media kartu bergambar. Berpedoman pada pendidikan anak usia dini sebagai tonggak untuk kelanjutan pendidikan pada tingkat diatasnya, maka kiprah atau peran guru pada pendidikan anak usia dini memang sangat berat, karena sebagai penentu atas maju atau mundurnya pendidikan. Sehubungan dengan hal tersebut di atas maka program metode maupun upaya untuk mencapai prestasi belajar yang tinggi dan maksimal salah satu faktor utamanya adalah membaca. 
Modal awal dari kompetensi membaca adalah mengenal huruf. Mengenal huruf adalah salah satu kompetensi yang wajib dikembangkan oleh guru pada pendidikan usia dini, dengan kompetensi ini diharapkan anak dapat mengenal Aksorn Thailand, sehingga nantinya anak tidak mengalami kesulitan dalam mengembangkan kompetensi berbahasanya khusunya pada kompetensi menulis.

Penelitian ini menggunakan kartu aksorn Thailand bergambar sebagai media atau benda konkret yang dapat digunakan anak saat belajar membaca aksorn Thailand, sehingga dapat membantu anak dalam mengenal dan memahami lafal huruf dan bentuknya.

Berdasarkan hal-hal tersebut di atas, maka kegiatan pembelajaran dengan menerapkan metode permainan dengan media kartu bergambar dapat memberikan stimulasi pada anak untuk mengembangkan kemampuannya dalam membaca aksorn Thailand. Oleh karena itu, penelitian ini bertujuan menguji keefektifan dan mendeskripsikan hasil penggunaan metode permainan media kartu bergambar dalam meningkatkan kemampuan membaca Aksorn pada PAUD Ban Klong-To di Thailand.

\section{METODE}

Penelitian ini merupakan penelitian pre eksperimen dengan desain One Group Pretest Posttest. Subjek penelitian ini adalah siswa kelompok B PAUD Ban Klong-To sejumlah 25 siswa, 15 siswa laki-laki dan 10 siswa perempuan. Desain penelitian ini dpat digambarkan sebagai berikut.

\section{$\mathbf{O}_{1} \times \mathbf{O}_{2}$}

Gambar 1. Desain Penelitian One Group PretestPosttest

Keterangan:

O1: Pretest diberikan sebelum menggunakan treatment.

$\mathrm{X}$ : Treatment atau perlakuan berupa pembelajaran dengan metode permainan media kartu bergambar.
O2: Posttest diberikan setelah menggunakan treatment.

Sumber data penelitian ini berasal dari siswa dan guru. Variabel bebas yang digunakan yaitu permainan media kartu bergambar. Variabel terikat pada penelitian ini yaitu kemampuan membaca Aksorn pada anak usia dini. Hasil kemampuan membaca diperoleh melalui hasil posttest.

\section{HASIL DAN PEMBAHASAN}

Data hasil kemampuan membaca Aksorn terdiri dari pretest dan posttest. Hasil belajar pretest berdistribusi normal dan homogen. Sedangkan data hasil posttest lebih besar dibandingkan dengan data hasil pretest.

\section{Uji Normalitas Pretest}

Uji normalitas digunakan untuk mengetahui data pretest pada kemampuan membaca Aksorn Thailand pada siswa kelompok B PAUD Ban Klong-To. Uji normalitas data berpengaruh terhadap teknik analisis data yang digunakan. Ketika data normal, maka peneliti menggunakan statistik parametrik. Uji normalitas data pretest ini menggunakan rumus Liliefors. Cara untuk mengetahui normal atau tidaknya data tersebut, Dilihat dari nilai $\alpha=5 \%$ pada kolom Liliefors. Jika nilai L-hitung < L-tabel maka dapat dikatakan data tersebut berdistribusi normal. Hasil uji normalitas pretest disajikan pada table 1 berikut.

Tabel 1. Uji Normalitas Pretest

\begin{tabular}{lc}
\hline \multicolumn{1}{c}{ Hasil Uji } & Kelompok B \\
\hline Mean & 3,4 \\
Standar Deviasi & 1 \\
Probabilitias & 0,05 \\
Liliefors & 0,886 \\
$\mathrm{~N}$ & 25 \\
Liliefors Tabel & 0,173 \\
Lilefors Hitung & 0,004 \\
\hline
\end{tabular}

Tabel 1 menyebutkan bahwa L-hitung skor pretest yaitu 0,004 lebih kecil dari L-tabel yaitu 0,173 , maka $\mathrm{H}_{0}$ diterima berarti data berdistribusi normal. 


\section{Uji Normalitas Posttest}

Uji normalitas digunakan untuk mengetahui data posttest pada kemampuan membaca Aksorn Thailand pada siswa kelompok B PAUD Ban Klong-To. Uji normalitas data berpengaruh terhadap teknik analisis data yang digunakan. Ketika data normal, maka peneliti menggunakan statistik parametrik. Uji normalitas data posttest ini menggunakan rumus Liliefors. Cara untuk mengetahui normal atau tidaknya data tersebut. Dilihat dari nilai $\alpha=5 \%$ pada kolom Liliefors. Jika nilai L-hitung < L-tabel maka dapat dikatakan data tersebut berdistribusi normal. Hasil uji normalitas pretest disajikan pada tabel 2 berikut.

Tabel 2. Uji Normalitas Posttest

\begin{tabular}{lc}
\hline \multicolumn{1}{c}{ Hasil Uji } & Kelompok B \\
\hline Mean & 7,16 \\
Standar Deviasi & 0,746 \\
Probabilitias & 0,05 \\
Liliefors & 0,886 \\
$\mathrm{~N}$ & 25 \\
Liliefors Tabel & 0,173 \\
Lilefors Hitung & 0,001 \\
\hline
\end{tabular}

Sesuai dengan tabel 2 terlihat bahwa Lhitung skor posttest yaitu 0,001 lebih kecil dari Ltabel yaitu 0,173 , maka $\mathrm{H}_{0}$ diterima berarti data berdistribusi normal.

\section{Uji Homogenitas}

\section{Uji Homogenitas Pretest}

Uji homogenitas dilakukan untuk mengetahui terdapat kesamaan varian atau tidak pada suatu populasi. Ketika varian yang dimiliki oleh sampel yang bersangkutan tidak jauh berbeda, maka data sampel cukup homogen dan digeneralisasikan. Cara untuk mengetahui normal atau tidaknya data tersebut, kita melihat nilai $\alpha=5 \%$ pada tabel distribusi $F$. Jika nilai $F$ hitung < F-tabel maka dapat dikatakan data tersebut homogen. Uji homogenitas pretest pada penelitian ini menggunakan uji $\mathrm{F}$, disjikan dalam tabel 3 sebagai berikut.

Tabel 3. Uji Homogenitas Pretest

\begin{tabular}{ccc}
\hline F-hitung & F-tabel & Kesimpulan \\
\hline 0,185 & 1,96 & Homogen \\
\hline
\end{tabular}

Sesuai dengan tabel 3 dapat diketahui Fhitung 0,185 hasil pretest lebih kecil dibanding dengan F-tabel 1,96, maka $\mathrm{H}_{0}$ diterima yang berarti data homogen.

\section{Uji Homogenitas Posttest}

Uji homogenitas dilakukan untuk mengetahui terdapat kesamaan varian atau tidak pada suatu populasi. Ketika varian yang dimiliki oleh sampel yang bersangkutan tidak jauh berbeda, maka data sampel cukup homogen dan digeneralisasikan. Cara untuk mengetahui normal atau tidaknya data tersebut, kita melihat nilai $\alpha=5 \%$ pada tabel distribusi $\mathrm{F}$. jika nilai $\mathrm{F}$ hitung < F-tabel maka dapat dikatakan data tersebut homogen. Uji homogenitas posttest pada penelitian ini menggunakan uji $\mathrm{F}$, disajikan dalam tabel 4 sebagai berikut.

Tabel 4. Uji Homogenitas Posttest

\begin{tabular}{ccc}
\hline F-hitung & F-tabel & Kesimpulan \\
\hline 0,792 & 1,96 & Homogen \\
\hline
\end{tabular}

Sesuai dengan tabel 4 dapat diketahui Fhitung hasil posttest 0,792 lebih kecil dibanding dengan F-tabel 1,96, maka $\mathrm{H}_{0}$ diterima yang berarti data homogen.

\section{Uji Hipotesis Akhir}

Setelah dilaksanakan uji normalitas dan uji homogenitas, peneliti melaksanakan pengujian hipotesis akhir. Karena data berdistribusi normal dan memiliki kesamaan varian, peneliti menggunakan rumus Polled Varian. Di dalam uji-t berlaku ketentuan pengambilan keputusan nilai t-hitung dengan nilai t-tabel. Jika t-hitung $>$ t-tabel dapat ditarik kesimpulan bahwa $\mathrm{Ha}$ diterima dan $\mathrm{H}_{0}$ ditolak. Sebaliknya jika t-hitung < t-tabel maka dapat ditarik kesimpulan bahwa $\mathrm{Ha}$ ditolak dan $\mathrm{H}_{0}$ diterima. Dalam penelitian ini $\mathrm{H}_{0}$ mempunyai arti metode permainan kartu bergambar tidak efektif dalam meningkatkan kemampuan membaca Aksorn. Sedangkan Ha mempunyai arti arti metode permainan kartu bergambar efektif dalam meningkatkan kemampuan membaca Aksorn. Hasil uji-t disajikan pada table 5 berikut ini. 
Tabel 5. Pengujian Hipotesis Akhir (Uji-t)

\begin{tabular}{ccc}
\hline T-hitung & T-tabel & Kesimpulan \\
\hline 14,462 & 1,708 & $\mathrm{H}_{0}$ ditolak \\
\hline
\end{tabular}

Sesuai dengan tabel dapat diketahui bahwa t-hitung sebesar 14,462 lebih besar daripada t-tabel 1,708. Maka Ha diterima yang berarti kemampuan membaca Aksorn Thailand Kelompok B PAUD Ban Klong-To menggunakan metode permainan kartu bergambar efektif. Mengkaji lebih lanjut tentang pelaksanaan metode permainan media kartu bergambar, pemaknaan temuan penelitian dan implikasi hasil penelitian. Pemaknaan temuan penelitian meliputi hasil pretest dan posttest kemampuan membaca Aksorn Thailand pada siswa kelompok B di PAUD Ban Klong-To. Sedangkan implikasi hasil penelitian meliputi implikasi teoritis, praktis, dan pedagogis.

Penelitian yang dilaksanakan di kelompok B PAUD Ban Klong-To ini berawal dari sebuah permasalahan bahwa kemampuan anak khususnya dalam membaca Aksorn Thailand belum berkembang maksimal. Masalah ini terlihat ketika dilaksanakan observasi bahwa masih banyak anak yang belum mampu mengenali Aksorn Thailand dan mengidentifikasi bagaimana bentuk dan bunyi Aksorn Thailand. Pada hal menurut Suyanto (2005:169), "Anak usia 5-6 tahun sudah mulai dapat mengingat kata yang sering ia jumpai, menceritakan cerita yang pernah didengar, mengenal huruf abjad, dan tertarik terhadap berbagai huruf danacaan yang ada di lingkungannya". Pendapat didukung oleh Seefeldt \& Wasik (2008:323) yang menyebutkan bahwa "Anak akan dapat membaca apabila anak sudah memiliki kesadaran fonemik, pengetahuan tantang huruf, dan pemahaman tentang huruf cetak". Oleh karena itu masalah tersebut perlu pemecahan agar perkembangan anak khususnya perkembangan bahasa dalam membaca dapat berkembang optimal.

Penelitian ini berlangsung selama 6 minggu, dengan dua observasi dan empat kali eksperimen. Penelitian yang bertujuan meningkatkan kemampuan membaca Aksorn Thailand ini menggunakan metode permainan kartu. Metode ini dipilih dengan asumsi bahwa bagi "Anak taman kanak-kanak adalah bermain dan bermain sambil balajar" (Moeslichatoen (1999:25).

Metode permainan kartu ini terbukti dapat meningkatkan kemampuan membaca pada anak. Analisis tahap awal dengan uji normalitas terhadap data nilai pretest didapatkan bahwa keduanya berdistribusi normal. Selanjutnya, pada uji homogenitas yang dilakukan terhadap nilai pretest didapatkan hasil yang menunjukkan bahwa variansi yang homogen. Hal ini berarti menunjukkan bahwa dari kondisi awal yang sama, sehingga dapat dilakukan penelitian. Penelitian ini diawali dengan pelaksanaan pembelajaran dengan materi membaca Aksorn Thailand sebanyak empat kali pertemuan.

Analisis akhir dilakukan terhadap data nilai posttest. Nilai posttest menunjukkan bahwa nilai rata-rata semakin tinggi dibandingkan dengan nilai pretest. Sebelum dilakukan analisis akhir maka dilakukan terlebih dahulu pengujian prasyarat yaitu uji normalitas dan uji homogenitas, dengan uji normalitas terhadap data nilai pretest didapatkan bahwa berdistribusi normal. Selanjutnya, pada uji homogenitas yang dilakukan terhadap nilai pretest didapatkan hasil yang menunjukkan bahwa mempunyai variansi yang homogen. Setelah didapatkan bahwa hasil nilai posttest berdistribusi normal dan homogen maka statistika yang digunakan untuk statistika akhir adalah statistika parametrik. Uji analisis akhir digunakan untuk mengetahui keefektifan penggunaan metode permainan media kartu bergambar.

Hasil uji analisis akhir menujukkan bahwa metode permainan media kartu bergambar lebih efektif digunakan dalam pembelajaran membaca dan mengenal Aksorn Thailand dengan hasil uji bahwa t-hitung 14,462 lebih tinggi dibandingkan t-tabel 1,708. Hasil uji keefektifan penggunaan metode permainan media kartu bergambar juga didukung dengan Gain Score dengan nilai 0,75 dengan kategori tinggi. 
Pelaksanaan penggunaan metode permainan dengan media kartu ini merujuk pada hasil observasi yang telah dilakukan. Pada kegiatan observasi ada dua hal yang diamati ketika pembelajaran berlangsung yaitu pelaksanaan penggunaan metode permainan dengan media kartu dan aktivitas siswa yang terjadi ketika penggunaan metode permainan dengan media kartu bergambar berlangsung. Kegiatan awal dimulai dengan aktivitas senam dengan menggunakan irama musik di halaman sekolah, kemudian berbaris dan masuk ruang kelas secara teratur seperti biasanya. Setelah masuk di dalam kelas, anak diposisikan duduk melingkar untuk kegiatan pembukaan yaitu salam, berdoa dan apersepsi tentang kegiatan membaca Aksorn Thailand menggunakan metode permainan kartu bergambar. Guru menanyakan kabar anak, apakah anak belajar dirumah, dan apakah anak sudah mengenal banyak Aksorn Thailand. Guru juga memancing semangat anak dengan memberikan pertanyaan siapakah yang mendapat hadiah stiker bintang paling banyak, apakah hari ini anak mau mendapatkannya lagi, dan lain-lain. Kemudian guru menjelaskan kegiatan membaca Aksorn Thailand seperti yang pernah dilakukan anak pada hari sebelumnya.

Kegiatan membaca Aksorn Thailand melalui kartu kata meliputi 3 kegiatan yang sama seperti sebelumnya yaitu menyebutkan simbol Aksorn Thailand, menunjukkan simbol Aksorn Thailand, dan menghubungkan simbol Sara. Kemudian guru dan anak membuat kesepakatan aturan main secara bersama-sama dan memberikan motivasi secara verbal dan non verbal bahwa anak yang mampu menyelesaikan tugas dengan benar maka akan mendapat hadiah berupa stiker berbentuk bintang.

Berdasarkan lembar observasi pada pertemuan pertama pelaksanaan penggunaan metode permainan media kartu bergambar cukup, namun ada beberapa hal yang mempengaruhi pelaksanaannya menjadi kurang maksimal. Di awal pembelajaran siswa mengalami sedikit kesulitan dalam menerima pembelajaran dikarenakan siswa masih memerlukan adaptasi dengan penggunaan metode permainan media kartu bergambar.

Pada pertemuan kedua, ketiga, keempat, kelima dan keenam pelaksanaan penggunaan metode permainan media kartu berjalan dengan baik. Siswa merasa sudah terbiasa dengat alur pembelajaran penggunaan metode permainan media kartu bergambar hal tersebut ditunjukkan dengan siswa secara mandiri sudah memahami terkait apa yang harus dikerjakan di setiap penggunaan metode permainan media kartu yang sedang dilaksanakan sehingga memudahkan guru dalam melaksanaan penggunaan metode permainan media kartu dengan yang telah direncanakan.

Dalam penelitian ini, untuk mengetahui pemahaman awal siswa tentang materi kemampuan membaca Aksorn Thailand, maka peneliti melakukan pretest sebelum diberikan perlakuan atau treatment. Rata-rata hasil pretest 3,4 setelah dilakukan uji statitistik melewati tahapan uji normalitas dan uji homogen didapatkan bahwa hasil pretest menunjukkan bahwa kemampuan siswa terhadap membaca Aksorn Thailand cenderung rendah. Hal ini dikarenakan siswa hanya menghafal Aksorn, serta kemampuan membaca kata dengan imbuhan Sara kurang optimal.

Dalam mengetahui pemahaman akhir siswa tentang materi kemampuan membaca Aksorn Thailand, maka peneliti melakukan posttest setelah diberikan perlakuan atau treatment. Rata-rata hasil posttest 8,3 setelah dilakukan uji statitistik melewati tahapan uji normalitas dan uji homogen didapatkan bahwa hasil posttest menunjukkan bahwa kemampuan siswa terhadap membaca Aksorn Thailand cenderung meningkat. Hal ini dibuktikan dengan siswa mampu membaca Aksorn dengan fasih serta mampu membaca kata yang berimbuhan dengan Sara. Sebagaimana penelitian oleh Ali, Aziz, \& Majzub (2011), bahwa dengan bermain, kemampuan membaca semakin efektif. Demikian juga Herberg, McLaughlin, Derby, \& Gilbert (2011) mengemukakan setelah adanya permainan dengan kertu kemampuan membaca anak usia dini lebih meningkat. 


\section{SIMPULAN}

Metode permainan media kartu bergambar terbukti efektif meningkatkan kemampuan membaca Aksorn pada PAUD Ban Klong-To di Thailand. Sebagai data pendukung hasil uji gain score menunjukkan bahwa gain score yang menggunakan metode permainan media kartu bergambar sebesar 0,75 dengan kategori tinggi yang dibuktikan dengan mampu membaca dengan Aksorn dan Sara. Kemampuan membaca Aksorn ditandai dengan mampu membaca kata dengan benar, tanpa melihat gambar. Mampu membaca kata yang diimbuhkan dengan Sara.

Dari simpulan yang didapatkan, disarankan bahwa guru yang menggunakan metode permainan media kartu bergambar sebaiknya terlebih dahulu membuat ringkasan materi agar penyampaian materi terlaksana secara efektif dikarenakan waktu untuk penyampaian materi yang sangat terbatas. Metode permainan ini memiliki ciri khas bahwa siswa memilih topik yang diminati untuk dipelajari bersama teman yang memiliki kesamaan minat, sehingga rawan terjadi perselisihan. Guru yang menggunakan metode ini sebaiknya membuat rancangan manajemen waktu dikarenakan melibatkan kegiatan diskusi yang membutuhkan waktu cukup lama sebab siswa harus saling berdiskusi.

\section{DAFTAR PUSTAKA}

Ali, A., Aziz, Z., \& Majzub, R. (2011). Teaching and learning reading trough play. World Applied Sciences Journal, 14(4), 15-20.

Herberg, K., McLaughlin, T. F., Derby, K. M., \& Gilbert, V. (2011). The effects of direct instruction flashcards on shape recognition and recall for two preschool students with disabilities. Academic Research International, 1(3), 59-64.

Mansur. (2005). Pendidikan anak usia dini dalam Islam. Yogyakarta: Pustaka Pelajar.

Moeslichatoen, R. (1999). Metode pengajaran di taman kanak-kanak. Jakarta: Rineka Cipta.

Morisson, G. S. (2012). Dasar-dasar pendidikan anak usia dini (PAUD). Jakarta: Indeks.

Mulyati, Y. (2015). Keterampilan berbahasa Indonesia SD. Jakarta: Universitas Terbuka.

Musthofa, Y. (2007). EQ untuk anak usia dini dalam pendidikan Islam. Yogyakarta: Sketsa.

Patmonodewo, S. (2003). Pendidikan anak prasekolah. Jakarta: PT. Rineka Cipta.

Santrock, J. W. (2009). Child development (Twelfth edition). New York: McGraw Hill.

Seefeldt, C., \& Wasik, B. A. (2008). Pendidikan anak usia dini. Jakarta: PT Indeks.

Suyanto, S. (2005). Dasar-dasar pendidikan anak usia dini. Yogyakarta: Hikayat Publishing.

Zubaidah, E. (2004). Perkembangan bahasa anak usia dini dan teknik pengembangan di sekolah. Jurnal Cakrawala Pendidikan, 23(3), 459-479. 